\title{
Potential Donor Sites of the Parietal for Bone Grafting and its Relationship to the Cephalic Index
}

\author{
Sitios Donantes Potenciales del Hueso Parietal para \\ Injerto Óseo y su Relación con el Índice Cefálico
}

\author{
Atson Carlos de Souza Fernandes ${ }^{1}$; Raquel Strauch Costa $^{1} \&$ Márcio de Moraes $^{2}$
}

FERNANDES, A. C. S. ; COSTA, R. S. \& MORAES, M. Potential donor sites of the parietal for bone grafting and its relationship to the cephalic index. Int. J. Morphol., 35(3):986-991, 2017.

SUMMARY: The purpose of the present study was to chart the thickness of the parietal bone and establish its relationship with the cephalic index and sex aiming at improving current knowledge and guidance for obtaining calvarial bone auto-graft material. Both left and right parietal bones of 150 skulls of adult human cadavers classified as either dolicho-, meso-, or brachicephalic, and as either male or female had their thickness measured at 3 levels - superior $(\mathrm{S})$, middle $(\mathrm{M})$ and inferior $(\mathrm{I})$ - and at 3 points - anterior (a), middle (m) and posterior (p) - in each level, all evenly laid out. No relevant differences in thickness whether comparing sex or cephalic index was evidenced. The thickest measurements were found at points located at superior and middle levels in middle and posterior positioning - Sm, $\mathrm{Sp}, \mathrm{Mm}$ and $\mathrm{Mp}$ - with median values ranging from about $5.5 \mathrm{~mm}$ to $7.13 \mathrm{~mm}$. At inferior level and posterior positioning, thickness median values ranged from 4.71 to $5.84 \mathrm{~mm}$. Safer harvesting of bone graft material occurs in $\mathrm{Sm}$, Sp, Mm and Mp areas of the parietal bone. Only exceptionally should Ip domain be used, whereas Sa, Ia and Im regions should be considered non-donor sites.

KEY WORDS: Parietal bone; Cephalic index; Bone grafting; Oral surgery.

\section{INTRODUCTION}

Bone graft material is most commonly obtained from the mandible, iliac crest, tibia and calvarium (Vermeeren $e t$ al., 1996; Gutta \& Wait, 2009). Autogenous grafting is more frequently used as it can be collected at site and time of surgery, which assures lower chances of infection, and because of its intrinsic advantage of showing lower rates of rejection (Zins \& Whitaker, 1983; Ozaki \& Buchman, 1998).

The calvarium has been used worldwide as autogenous bone grafts donor bone in maxillofacial reconstruction (Smith \& Abramson, 1974; Zins \& Whitaker; Donovan et al., 1993), in reconstruction of the alveolar process in both the maxilla and mandible, as well as in procedures involving osseointegrated dental implants (Vermeeren et al.; Smolka et al., 2006; de Souza Fernandes et al., 2011).

Due to its dense cortical layer, the calvarium has proven to be a source of mechanically reliable bone grafts, which also show very limited resorption over the years (Smith \& Abramson; Le Lorch-Bukiet et al., 2005). Another feature of calvarial bone is that it contains higher levels of bone growth factors and earlier revascularization resulting in improved keeping of shape and volume of the material transplanted, besides showing improved healing of the donor site as compared with bone of endocondral origin. Moreover, the donor site is significantly nearer from the reconstruction site (Zins \& Whitaker; Kulali \& Kayaalp, 1991; Markowitz, 1992; Ozaki \& Buchman; Le Lorch-Bukiet et al.; de Souza Fernandes et al.).

Calvarial bone grafts can be taken from the occipital, temporal, and especially the parietal regions (Tessier, 1982; Zins \& Whitaker). Grafts from the parietal area provide bone of the appropriate shape for most facial applications, thus making the parietal the bone of choice to harvest bone graft material. Because of the thickness of the cortical layers of this calvarial bone, graft material can be harvested from the external cortex leaving the structures inside the cranial cavity intact (Pensler \& McCarthy, 1985; Cannella \& Hopkins, 1990; Frodel et al., 1993; Hwang et al., 2000; Smolka et al.; de Souza Fernandes et al.).

\footnotetext{
${ }^{1}$ Escola Bahiana de Medicina e Saúde Pública, Bahia, Brazil.

${ }^{2}$ Departamento de Diagnóstico Oral, Faculdade de Odontologia, Universidade de Campinas, São Paulo, Brazil.
} 
In order to assure optimal harvesting and safest surgical procedures, the donor site should be located in the thicker areas of the parietal bone.

The purpose of the present study was to determine the thickness of the parietal bone as well its relation with sex and cephalic index in the attempt to improve guidance for harvesting of calvarial bone graft material.

\section{MATERIAL AND METHOD}

This study received the approval of the institutional ethics committee of the Fundação Bahiana para Desenvolvimento das Ciências, Bahia, Brazil (CAAE N. 13156913.2.1001.5544) and was performed on 300 parietal bones of the 150 cadaveric human skulls of both male and female Brazilian adults obtained from the São Paulo Federal University and Bahia's School of Medicine and Public Health.

All the skulls studied classified as dolichocephalic (34 male/ 16 female), mesocephalic ( 29 male/ 32 female) and brachycephalic ( 21 male/ 18 female) were free from macroscopic abnormalities.

For assessing the cephalic index the Hrdlicka's method was used: the head-length (hl) - greatest anteroposterior diameter, and the head-breadth (hb) maximum transverse diameter between two fixed points were measured with the subjects positioned on a table.

The calculation result of (hb x 100)/hl defined the cephalic index: dolichocephalic (70.0 - 74.9), mesocephalic (75.0 - 79.9) and brachycephalic (80.0 - 84.9).

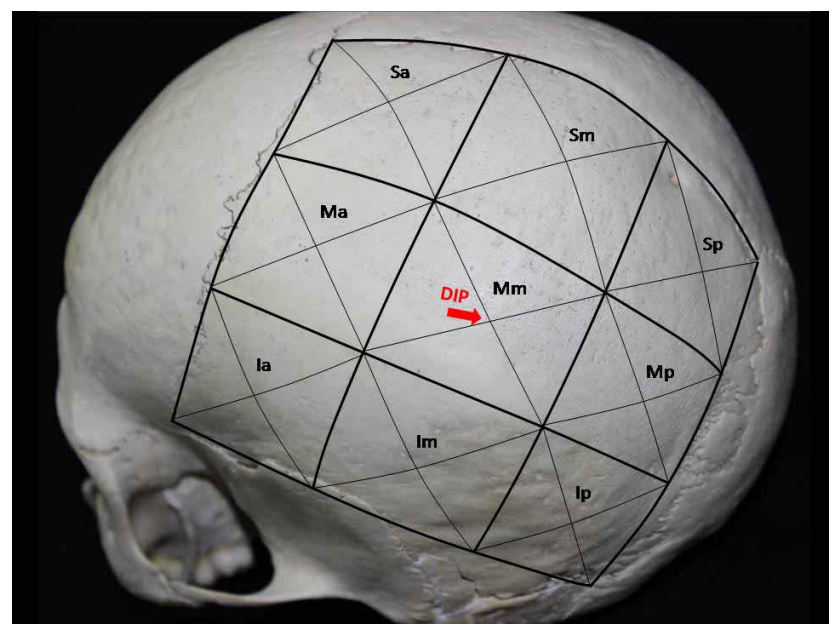

Fig. 1. Reference grid drawn on calvarial bone. Cells are identified and red arrow indicates the point at which thickness of the parietal was determined - DIP (diagonal intersection point).
Morphometric analysis. In order to establish a topological reference, a geometric figure with four straight sides was drawn on the parietal bone. The first two sides ran from the point Lambda to the point Bregma, and from the latter to that where the coronal suture first touched the sphenoid bone (Pterion). The third side linked the Pterion to the Asterion, and the forth side linked the Asterion to the point Lambda thus forming a "tridimensional tetragon".

Each of the four sides of the figure was divided into thirds and a grid was drawn as shown in Figure 1.

The cells determined by the grid were firstly named according their position running from the sagittal to the squamous suture as 'Superior', 'Middle' and 'Inferior', and secondly according to their location running from the coronal to the lambdoid suture as 'anterior', 'middle' and 'posterior'. These nine elements ordered as above mentioned were referred to as $\mathrm{Sa}$ (Superior-anterior), Sm (Superior-middle), $\mathrm{Sp}$ (Superior-posterior), Ma (Middle-anterior), Mm (Middlemiddle), Mp (Middle-posterior), Ia (Inferior-anterior), Im (Inferior-middle) and Ip (Inferior-posterior).

By simply intersecting diagonals in each of these cells, central points (DIP - diagonal intersection point) were established for thickness determination.

All measurements were performed using a precision electronic thickness gauge (model EOD 2050; Oditronic digital, Kroeplin, Germany) with minimum determination of $0.02 \mathrm{~mm}$.

Statistical analysis. Measurements relative to each cell of the reference grid were grouped by cephalic index and sex and descriptive statistics were calculated for each group. Since previous principal component analysis showed dependence between cephalic index measures, comparisons were performed using false discovery rate (FDR) with Benjamini-Yekutieli adjustment.

The FDR is a technique used when multiple statistical comparisons (hypothesis testing) are performed simultaneously to correct $\mathrm{p}$ values, since the global level of significance, generally alpha equals 0.05 , ceases to be the same in such a situation. However, the Benjamini-Yekutieli adjustment is performed over the $\mathrm{p}$ values obtained by FDR when the measures (cephalic index) have dependency with one another.

Statistical significance was set to adjusted FDR $\mathrm{p} \leq$ 0.05 and calculations were carried out using the free software ' $R$ ' 2013version (The $R$ project for statistical computing) available at www.r-project.org. 


\section{RESULTS}

Examining each level - Superior, Middle and Inferior - individually and regardless of the skull side, the cell or cells showing the statistically significant largest median value of thickness (MT) at DIP for cephalic index and sex were as follows:

Male dolichocephalic skulls: MT= $6.96 \mathrm{~mm}$ in superior middle cell; $\mathrm{MT}=6.66 \mathrm{~mm}$ in superior posterior cell; $\mathrm{MT}=5.23$ to $5.62 \mathrm{~mm}$ in middle anterior, middle and posterior cells with no statistically significant difference between MT values; and MT $=5.83 \mathrm{~mm}$ in inferior posterior cell (Table I).

Female dolichocephalic skulls: MT $=6.85 \mathrm{~mm}$ in superior middle cell; MT $=6.73 \mathrm{~mm}$ in superior posterior cell; MT $=6.15 \mathrm{~mm}$ in middle middle cell; and MT $=4.71 \mathrm{~mm}$ in Inferior posterior cell (Table I).
Male mesocephalic skulls: $\mathrm{MT}=7.13 \mathrm{~mm}$ in superior middle cell; $\mathrm{MT}=7.14 \mathrm{~mm}$ in superior posterior cell; MT $=5.02$ to $5.50 \mathrm{~mm}$ in middle anterior, middle and posterior cells with no statistically significant difference between MT values; and MT $=5.51 \mathrm{~mm}$ in inferior posterior cell (Table II).

Female mesocephalic skulls: MT $=7.12 \mathrm{~mm}$ in superior middle cell; $\mathrm{MT}=6.54 \mathrm{~mm}$ in middle middle cell; and $\mathrm{MT}=5.34 \mathrm{~mm}$ in inferior posterior cell (Table II).

Male brachicephalic skulls: MT $=6.78 \mathrm{~mm}$ in superior middle cell; $\mathrm{MT}=5.25$ to $5.47 \mathrm{~mm}$ in middle anterior, middle and posterior cells with no statistically significant difference between MT values; and MT $=5.61 \mathrm{~mm}$ in Inferior posterior cell (Table III).

Table I. Male and Female dolicephalic median thickness values in millimeters, and corresponding False Discovery Rate (FDR) multiple comparison between anterior, middle and posterior cells in the same level Superior, Middle and Inferior of the reference grid.

\begin{tabular}{lllllll}
\hline & $\begin{array}{l}\text { Males } \\
(\mathrm{n}=68)\end{array}$ & & & $\begin{array}{l}\text { Females } \\
(\mathrm{n}=32)\end{array}$ & \\
\hline Param eters & Median & Iqr* & $\begin{array}{l}\text { Signifcant comparison } \\
\text { (FDR)/ Adjusted p-value }\end{array}$ & Median & Iqr* & $\begin{array}{l}\text { Signifcant comparison } \\
\text { (FDR)/ Adjusted p-value }\end{array}$ \\
\hline $\mathrm{Sa}$ & 6 & 1.445 & $\mathrm{Sm}>\mathrm{Sa} * 0.00000$ & 5.11 & 1.35 & $\mathrm{Sm}>\mathrm{Sa} * 0.00003$ \\
$\mathrm{Sm}$ & 6.96 & 1.956 & $\mathrm{Sp}>\mathrm{Sa} * 0.00001$ & 6.85 & 1.296 & $\mathrm{Sp}>\mathrm{Sa} * 0.00047$ \\
$\mathrm{Sp}$ & 6.66 & 1.573 & $\mathrm{Sm}=\mathrm{Sp}$ & 6.73 & 1.476 & $\mathrm{Sm}=\mathrm{Sp}$ \\
$\mathrm{Ma}$ & 5.47 & 1.082 & & 4.97 & 1.412 & $\mathrm{Mm}>\mathrm{Ma} * 0.00020$ \\
$\mathrm{Mm}$ & 5.23 & 1.64 & $\mathrm{Ma}=\mathrm{Mm}=\mathrm{Mp}$ & 6.15 & 1.632 & $\mathrm{Ma}=\mathrm{Mp}$ \\
$\mathrm{Mp}$ & 5.62 & 1.346 & & 5.47 & 1.195 & $\mathrm{Mm}=\mathrm{Mp}$ \\
$\mathrm{Ia}$ & 3.85 & 1.028 & $\mathrm{Ip}>\mathrm{Ia} * 0.00000$ & 3.45 & 1.15 & $\mathrm{Ip}>\mathrm{Ia} * 0.00000$ \\
$\mathrm{Im}$ & 3.64 & 0.975 & $\mathrm{Ip}>\mathrm{Im} * 0.00000$ & 3.48 & 0.806 & $\mathrm{Ip}>\mathrm{Im} * 0.00001$ \\
$\mathrm{Ip}$ & 5.83 & 1.252 & $\mathrm{Ia}=\mathrm{Im}$ & 4.71 & 1.227 & $\mathrm{Ia}=\mathrm{Im}$ \\
\hline
\end{tabular}

Table II. Male and Female mesocephalic median thickness values in millimeters, and corresponding False Discovery Rate (FDR) multiple comparison between anterior, middle and posterior cells in the same level Superior, Middle and Inferior of the reference grid.

\begin{tabular}{ccccccc}
\hline & & \multicolumn{3}{c}{$\begin{array}{c}\text { Males } \\
(\mathrm{n}=58)\end{array}$} & & $\begin{array}{c}\text { Females } \\
(\mathrm{n}=64)\end{array}$ \\
\hline Parameters & Median & $\mathbf{I q r} *$ & $\begin{array}{c}\text { Signifcant comparison (FDR)/ } \\
\text { Adjusted p-value }\end{array}$ & $\begin{array}{c}\text { Media } \\
\mathbf{n}\end{array}$ & Iqr* & $\begin{array}{c}\text { Signifcant comparison (FDR)/ } \\
\text { Adjusted p-value }\end{array}$ \\
\hline $\mathrm{Sa}$ & 5.52 & 1.32 & $\mathrm{Sm}>\mathrm{Sa} * 0.00000$ & 4.925 & 1.247 & $\mathrm{Sm}>\mathrm{Sa} * 0.00003$ \\
$\mathrm{Sm}$ & 7.13 & 1.39 & $\mathrm{Sp}>\mathrm{Sa} * 0.00002$ & 7.12 & 1.64 & $\mathrm{Sp}>\mathrm{Sa} * 0.00047$ \\
$\mathrm{Sp}$ & 7.14 & 1.3 & $\mathrm{Sm}=\mathrm{Sp}$ & 6.79 & 1.352 & $\mathrm{Sm}-\mathrm{Sp} * 0.00269$ \\
$\mathrm{Ma}$ & 5.02 & 1.28 & $\mathrm{Ma}=\mathrm{Mm}=\mathrm{Mp}$ & 5.71 & 1.279 & $\mathrm{Mm}>\mathrm{Ma} * 0.00117$ \\
$\mathrm{Mm}$ & 5.69 & 1.23 & & 6.54 & 2.02 & $\mathrm{Ma}=\mathrm{Mp}$ \\
$\mathrm{Mp}$ & 5.5 & 1.22 & & 5.85 & 1.185 & $\mathrm{Mm}-\mathrm{Mp} * 0.00196$ \\
$\mathrm{Ia}$ & 3.8 & 0.89 & $\mathrm{Ip}>\mathrm{Ia} * 0.00000$ & 4.1 & 1.042 & $\mathrm{Ip}>\mathrm{Ia} * 0.00000$ \\
$\mathrm{Im}$ & 3.24 & 0.77 & $\mathrm{Ip}>\mathrm{Im} * 0.00000$ & 3.98 & 1.16 & $\mathrm{Ip}>\mathrm{Im} * 0.00000$ \\
$\mathrm{Ip}$ & 5.51 & 1.12 & $\mathrm{Ia}=\mathrm{Im}$ & 5.335 & 1.305 & $\mathrm{Ia}=\mathrm{Im}$ \\
\hline
\end{tabular}


Female braquicephalic skulls: MT= $6.50 \mathrm{~mm}$ in superior middle cell; $\mathrm{MT}=6.55 \mathrm{~mm}$ in superior posterior cell;
MT= $6.85 \mathrm{~mm}$ in middle middle cell; and MT= $5.84 \mathrm{~mm}$ in inferior posterior cell (Table III).

Table III. Male and Female brachicephalic median thickness values in millimeters, and corresponding False Discovery Rate (FDR) multiple comparison between anterior, middle and posterior cells in the same level Superior, Middle and Inferior of the reference grid.

\begin{tabular}{|c|c|c|c|c|c|c|}
\hline & & & $\begin{array}{l}\text { Males } \\
\mathrm{n}=42 \text { ) }\end{array}$ & & & $\begin{array}{l}\text { Females } \\
(\mathrm{n}=36)\end{array}$ \\
\hline Parameters & Median & Iqr* & $\begin{array}{l}\text { Signifcant comparison } \\
\text { (FDR)/ Adjusted p-value }\end{array}$ & Median & Iqr* & $\begin{array}{l}\text { Signifcant comparison (FDR)/ } \\
\text { Adjuste d p-value }\end{array}$ \\
\hline Sa & 5.14 & 1.52 & $\mathrm{Sm}>\mathrm{Sa} * 0.00000$ & 5 & 0.96 & $\mathrm{Sm}>\mathrm{Sa} * 0.00004$ \\
\hline Sm & 6.78 & 1.39 & $\mathrm{Sm}>\mathrm{Sp} * 0.00000$ & 6.5 & 1.19 & \\
\hline Sp & 6.06 & 1.41 & $\mathrm{Sa}=\mathrm{Sp}$ & 6.55 & 1.039 & $\begin{array}{l}\mathrm{Sp}>\mathrm{Sa} * 0.00016 \\
\quad \mathrm{Sm}=\mathrm{Sp}\end{array}$ \\
\hline Ma & 5.25 & 1.05 & $\mathrm{Ma}=\mathrm{Mm}=\mathrm{Mp}$ & 5.6 & 1.3 & \\
\hline Mm & 5.36 & 1.26 & & 6.85 & 1.74 & $\mathrm{Mm}>\mathrm{Ma} * 0.00237$ \\
\hline Mp & 5.47 & 1.07 & & 5.67 & 1.031 & $\begin{array}{c}\mathrm{Ma}=\mathrm{Mp} \\
\mathrm{Mm} \_\mathrm{Mp} * 0.1746\end{array}$ \\
\hline Ia & 4.14 & 1.29 & Ip > Ia *0.00000 & 4.3 & 1.03 & $\mathrm{Ip}>\mathrm{Ia} * 0.00018$ \\
\hline Im & 3.16 & 0.67 & $\operatorname{Ip}>\operatorname{Im} * 0.00000$ & 3.98 & 1.12 & $\operatorname{Ip}>\operatorname{Im} * 0.00002$ \\
\hline Ip & 5.61 & 1.37 & $\mathrm{Ia}=\mathrm{Im}$ & 5.84 & 0.99 & $\mathrm{Ia}=\mathrm{Im}$ \\
\hline
\end{tabular}

\section{DISCUSSION}

The increased resistance to resorption shown by calvarial bone when used as onlay bone grafts has been attributed to its embryologic origin, which confers earlier revascularization, inherent architecture, and increased osteoblastic and decreased osteoclastic activity when compared with iliac bone grafts (Zins \& Whitaker; Smolka et al.).

As a flat bone, the parietal has two cortical layers of hard and compact material which encloses a layer of spongy cancelous structural matrix, the diploe (Frodel et al.). Running along and just under the sagittal suture - the 1-to-1.5centimeter wide zigzag junction of the right and left parietal bones - is one of the most important subcortical structures, the superior sagittal sinus, a triangular, noncollapsible, intradural venous sinus that averages $23 \mathrm{~cm}$ in length (Cannella \& Hopkins).

The thickness of the parietal bone makes graft collection viable. Nonetheless, harvesting in thicker areas makes neurosurgical complications less likely to occur (Markowitz; Frodel et al.; Hwang et al., 2000; Jung et al., 2003; de Souza Fernandes et al.).

Many studies of the thickness of the parietal bone have been carried out in cadavers and radiographic imaging, and has related thickness to age, sex and race (Pensler \& McCarthy; Frodel et al.; Hwang et al., 1997; Hwang et al., 2000; Jung et al.; Le Lorch-Bukiet et al.; de Souza Fernandes et al.).
There is a consensus on obtaining bone graft material from parietal in the area adjacent to the sagittal suture - Sa, $\mathrm{Sm}$ and $\mathrm{Sp}$ according the reference system used in the present study - keeping the distance of 1 to $3 \mathrm{~cm}$ away from this suture to prevent injury to the superior sagittal sinus (Frodel et al.). However, further recommendations vary among authors. Edwards \& Ousterhout (1987) recommend that the graft should be taken from the medial and posterior thirds of the parietal, which correspond to Sm and Sp in the present study. On the other hand, Sullivan \& Smith (1989) and Kohan et al. (1989) recommend that harvesting should be carried out in the anterior third $(\mathrm{Sa}), 2 \mathrm{~cm}$ away from the coronal suture and $1,5 \mathrm{~cm}$ away from the sagittal suture. Still other authors recommend harvesting in the area neighboring the sagittal suture $-\mathrm{Sa}, \mathrm{Sm}$ and Sp - indistinctly (Tessier; Cannella \& Hopkins).

However, being able to obtain bone graft material from other areas of the parietal improves the possibilities of harvesting concerning amount and shape needed.

Aiming at providing a guide for calvarial bone harvesting in Korean people, Jung et al. studied the parietal bone of 47 cadavers of Korean adults. The authors reported no statistically significant differences in thickness of corresponding sites in left and right parietal bones. They also found a tendency to larger values for measurements running away from the coronal and closer to the sagittal sutures, with the thickest points located simultaneously close to the lambdoid and sagittal sutures $-7.169 \mathrm{~mm}$ and $7.081 \mathrm{~mm}$, on the right and left parietal, respectively.

Another study on 88 Korean adults by Hwang et al. 
(1997) reported that thickness in some parietal bones varied widely depending on where the measurement was taken. The authors found that the bone was thickest near the lambda and sagittal sutures $(6.67 \mathrm{~mm})$, and thinnest near the pterion $(4.73$ $\mathrm{mm}$ ) with decreasing values running from the former to the latter location.

Pensler \& McCarthy published a study in 200 fresh adult cadavers in which they measured the calvarial thickness at four selected points on each side of the skull. They found that the thickest points - average of $7.72 \mathrm{~mm}$ - were located most posteriorly and the thinnest ones - average of $6.80 \mathrm{~mm}$ -most anteriorly. According to these authors, the parietal bone in Afro-Americans was thicker than in Caucasians, and men had a thicker parietal than women.

Sullivan \& Smith studied the thickness of 37 calvaria of adult cadavers reporting the thickness of $6.4 \mathrm{~mm}$ in an area of the parietal bone corresponding to Ma in our reference grid.

In a study on parietal thickness carried out by Kim \& Kim (1986) in 24 adult cadavers, the thinnest measurement was reported to be $3.6 \mathrm{~mm}$ and the thickest $10.9 \mathrm{~mm}$. The study mean values ranged from 5.9 to $6.8 \mathrm{~mm}$ with data analysis showing a tendency to increased thickness toward the posterior area of the parietal.

In our study the parietal bone thickness ranged from 1.88 to $12.26 \mathrm{~mm}, 1.71$ to $9.80 \mathrm{~mm}$ and 2.00 to $11.16 \mathrm{~mm}$ in dolichocephalic, mesocephalic and brachicephalic males, respectively. In dolichocephalic, mesocephalic and brachicephalic females, it ranged from 1.70 to $10.54 \mathrm{~mm}, 1.84$ to $13.32 \mathrm{~mm}$ and 2.48 to $10.62 \mathrm{~mm}$, respectively.

In all cases the thinnest measurements were observed in the inferior level of the grid - cells Ia and Im - with no statistically significant difference of values when comparing these cells. The finding concerning the thinnest area of the parietal seems to agree with that reported by Hwang et al. (1997) whose thinnest determination was near the pterion.

In the present study, unlike the thinnest location, the thickest sites varied when comparing cephalic indexes and sexes. In dolicho- and mesocephalic males the thickest determinations were in cell $\mathrm{Sp}(12.26 \mathrm{~mm}$ and $9.80 \mathrm{~mm}$, respectively), a finding similar to that reported by Hwang $e t$ al. (1997), Jung et al. and Kim \& Kim. In braquicephalic males and mesocephalic females it was in cell Sm $(11.16 \mathrm{~mm}$ and $13.32 \mathrm{~mm}$, respectively), whereas in brachi- and dolichocephalic females it was in cell $\mathrm{Mm}(10.62 \mathrm{~mm}$ and $10.54 \mathrm{~mm}$, respectively).

According statistical comparing of the thickness at each level, considering sex and cephalic index, we found that at the superior level the thickest areas were superior-middle (Sm) and superior-posterior $(\mathrm{Sp})$ for dolichocephalic male $(6.96 \mathrm{~mm} /$ $6.66 \mathrm{~mm})$ and female $(6.85 \mathrm{~mm} / 6.73 \mathrm{~mm})$, mesocephalic male $(7.13 \mathrm{~mm} / 7.14 \mathrm{~mm})$ and brachicephalic female $(6.50 \mathrm{~mm} /$ $6.55 \mathrm{~mm}$ ). For mesocephalic female and brachicephalic male, the thickest area was superior-middle ( $\mathrm{Sm}), 7.12 \mathrm{~mm}$ and 6.78 $\mathrm{mm}$ respectively.

At the middle level the thickest area was midlle-middle $(\mathrm{Mm})$ for dolichocephalic, mesocephalic and brachicephalic female, $6.15 \mathrm{~mm}, 6.54 \mathrm{~mm}$ and $6.85 \mathrm{~mm}$ respectively.

A particular finding of the present study was that the middle cells of the grid (Ma, Mm, and $\mathrm{Mp}$ ) showed median values of thickness with no statistically significant difference in virtually all subject skulls - dolico-, meso- or brachicephalic from males or females.

A distinct feature evidenced in this study is that the thickness median value at the center of the posterior cell (Ip) in the Inferior range of the parietal bone, is clearly larger than those determined in Inferior anterior and Inferior middle cells (Ia and Im, respectively) for all the three cephalic indexes in both sexes.

Based on our study, the areas that must be avoided to harvest parietal bone graft, independent of the cephalic index and sex, are Sa, Ia and Im.

Regardless of cephalic index, sex and any particular safety criteria, the data of the present study show that the location of first choice for harvesting bone graft material is that encompassing cells $\mathrm{Sm}$ and $\mathrm{Sp}$ cells. In the instance that $\mathrm{Sm}$ and Sp cannot fulfill the need for graft material, $\mathrm{Mm}$ and Mp should be the next areas of choice.

We do not investigate differences between sides because anterior studies have shown that there is no significant difference in this kind of comparing (Hwang et al, 1997; Jung et al.; de Souza Fernandes et al.).

The volume of graft material provided by Sm, Sp, Mm and $\mathrm{Mp}$ on both right and left sides is usually enough, for maxillofacial reconstruction procedures.

The average thickness of parietal bone in our study was thicker than those reported by Psillakis et al. (1986) and Jung et al. However it was closer to that determined by Sullivan \& Smith $-6,4 \pm 1.8 \mathrm{~mm}$. Although Pensler \& McCarthy have reported differences in thickness associated with sex, such association was not found in the current study nor in other studies retrieved from the literature (Kim \& Kim; Hwang et al, 2000; de Souza Fernandes et al.). 
The magnitude of the difference in thickness associated with cephalic index evidenced in our study seems not to be enough to require different approaches concerning safety when dealing with it.

We deem that the mapping of parietal bone thickness offered by the present study may be a useful tool for professionals in the field of maxillofacial reconstruction providing care to Brazilian patients.

It is important to mention that preoperative planning using CT scan is necessary to confirm the thickness of parietal bone and to identify anatomical variations that could putting at risk surgery.

This study received the approval of the institutional ethics committee.

FERNANDES, A. C. S. ; COSTA, R. S. \& MORAES, M. Sitios donantes potenciales del hueso parietal para injerto óseo y su relación con el Índice cefálico. Int. J. Morphol., 35(3):986-991, 2017.

RESUMEN: El propósito del estudio fue medir el grosor del hueso parietal y establecer su relación con el índice cefálico y el sexo, con el objetivo de mejorar el conocimiento actual y la orientación para el auto-injerto de material óseo. Fueron estudiados huesos parietales, tanto izquierdos como derechos, de 150 cráneos de cadáveres humanos adultos, de hombres y mujeres, clasificados como dolico-, meso- o braquicefálico; el espesor fue medido en 3 niveles: superior (S), medio (M) e inferior (I) - y en 3 puntos - anterior (a), medio ( $m$ ) y posterior (p) - en cada nivel, todas uniformemente establecidas. No se observaron diferencias relevantes en el grosor a nivelrespecto del sexo o el índice cefálico. Las mediciones más gruesas se encontraron en los puntos situados en los niveles superior y medio, y en posiciones medias y posteriores - Sm, Sp, Mm y Mp - con valores medianos que oscilaban entre aproximadamente $5,5 \mathrm{~mm}$ y $7,13 \mathrm{~mm}$. En el nivel inferior y posicionado posterior, los valores medianos del espesor oscilaron entre 4,71 y $5,84 \mathrm{~mm}$. La recolección más segura del material de injerto óseo ocurre en las áreas Sm, Sp, Mm y Mp del hueso parietal. Sólo excepcionalmente se debe utilizar el dominio Ip, mientras que las regiones $\mathrm{Sa}$, Ia e Im deben considerarse sitios no donantes.

PALABRAS CLAVE: Hueso parietal; Índice cefálico; Injerto óseo; Cirugía Oral.

\section{REFERENCES}

Cannella, D. M. \& Hopkins, L. N. Superior sagittal sinus laceration complicating an autogenous calvarial bone graft harvest: Report of a case. J. Oral Maxillofac. Surg., 48(7):741-3, 1990.

de Souza Fernandes, A. C.; Neto, A. I.; de Freitas, A. C. \& de Moraes, M. Dimensional analysis of the parietal bone in areas of surgical interest and relationship between parietal thickness and cephalic index. J. Oral Maxillofac. Surg., 69(11):2930-5, 2011.

Donovan, A. D.; Djakic, A. W.; Ioannides, N. S.; Garfield, T. R. \& Jones, C. $R$. Sequence Stratigraphic Control on Middle and Upper Jurassic Reservoir Distribution within the UK Central North Sea. In: Parker, J. R. (Ed.). Petroleum Geology of Northwest Europe: Proceedings of the $4^{\text {th }}$ Conference. London, Geological Society, 1993. pp.251-69.
Edwards, M. S. \& Ousterhout, D. K. Autogeneic skull bone grafts to reconstruct large or complex skull defects in children and adolescents. Neurosurgery, 20(2):273-80, 1987.

Frodel, J. L. Jr.; Marentette, L. J.; Quatela, V. C. \& Weinstein, G. S. Calvarial bone graft harvest. Techniques, considerations, and morbidity. Arch. Otolaryngol. Head Neck Surg., 119(1):17-23, 1993.

Gutta, R. \& Wait, P. D. Outcomes of calvarial bone grafting for alveolar ridge reconstruction. Int. J. Oral Maxillofac. Implants, 24(1):131-6, 2009.

Hwang, K.; Hollinger, J. O.; Chung, R. S. \& Lee, S. I. Histomorphometry of parietal bones versus age and race. J. Craniofac. Surg., 11(1):17-23, 2000.

Hwang, K.; Kim, J. H. \& Baik, S. H. Thickness map of parietal bone in Korean adults. J. Craniofac. Surg., 8(3):208-12, 1997.

Jung, Y. S.; Kim, H. J.; Choi, S. W.; Kang, J. W. \& Cha, I. H. Regional thickness of parietal bone in Korean adults. Int. J. Oral Maxillofac. Surg., 32(6):63841, 2003.

Kim, Y. J. \& Kim, C. W. A survey on thinckness of the Korean calvarium. J. Korean Soc. Plast. Reconstr. Surg., 13:147-54, 1986.

Kohan, D.; Plasse, H. M. \& Zide, B. M. Frontal bone reconstruction with split calvarial and cancellous iliac bone. Ear Nose Throat J., 68(11):8456, 1989.

Kulali, A. \& Kayaalp, S. Single-table autogenous calvarial grafting for cranioplasty. J. Craniomaxillofac. Surg., 19(5):208-11, 1991.

Le Lorc'h-Bukiet, I.; Tulasne, J. F.; Llorens, A. \& Lesclous, P. Parietal bone as graft material for maxillary sinus floor elevation: structure and remodeling of the donor and of recipient sites. Clin. Oral Implants Res., 16(2):244-9, 2005.

Markowitz, N. R. Cranial bone grafting in oral and maxillofacial surgery. $J$. Am. Dent. Assoc., 123(7):206-11, 1992.

Ozaki, W. \& Buchman, S. R. Volume maintenance of onlay bone grafts in the craniofacial skeleton: micro-architecture versus embryologic origin. Plast. Reconstr. Surg., 102(2):291-9, 1998.

Pensler, J. \& McCarthy, J. G. The calvarial donor site: an anatomic study in cadavers. Plast. Reconstr. Surg., 75(5):649-51, 1985.

Psillakis, J. M.; Grotting, J. C.; Casanova, R.; Cavalcante, D. \& Vasconez, L. O. Vascularized outer-table calvarial bone flaps. Plast. Reconstr. Surg., 78(3):309-17, 1986.

Smith, J. D. \& Abramson, M. Membranous vs endochondrial bone autografts. Arch. Otolaryngol., 99(3):203-5, 1974.

Smolka, W.; Eggensperger, N.; Carollo, V.; Ozdoba, C. \& Iizuka, T. Changes in the volume and density of calvarial split bone grafts after alveolar ridge augmentation. Clin. Oral Implants Res., 17(2):149-55, 2006.

Sullivan, W. G. \& Smith, A. A. The split calvarial graft donor site in the elderly: a study in cadavers. Plast. Reconstr. Surg., 84(1):29-31, 1989.

Tessier, P. Autogenous bone grafts taken from the calvarium for facial and cranial applications. Clin. Plast. Surg., 9(4):531-8, 1982.

Vermeeren, J. I.; Wismeijer, D. \& van Waas, M. A. One-step reconstruction of the severely resorbed mandible with onlay bone grafts and endosteal implants. A 5-year follow-up. J. Oral Maxillofac. Surg., 25(2):112-5, 1996.

Zins, J. E. \& Whitaker, L. A. Membranous versus endochondral bone: implications for craniofacial reconstruction. Plast. Reconstr. Surg., 72(6):778-85, 1983.

Corresponding author:

Atson Carlos de Souza Fernandes

Rua Silveira Martins, 3386, Cabula

CEP: 41.150 .100

Salvador, Bahia - BRAZIL

E-mail: atsonfernandes@yahoo.com.br

Received: 16-03-2017

Accepted: 19-05-2017 